\section{THE PERCY SLADEN TRUST EXPEDITION TO THE INDIAN OCEAN. FURTHER EXPLORATIONS. ${ }^{1}$}

TO complete the work of the above expedition I left in June last for the Seychelles, accompanied by $\mathrm{Mr}$. H. Scott and Mr. J. C. F. Fryer as naturalists. We arrived there on July 1o, but were unfortunately detained on Long Island, the quarantine station, for ten days. The time, however, was by no means wasted, as the island was fairly representative of low-country coco nut cultivation, and contained a fairly rich insect fauna, mainly of introduced species. We had boats also, and were thus enabled to examine the reefs in its vicinity, collecting particularly the sedentary organisms.

On July 23 I sent $\mathrm{Mr}$. Fryer to examine Bird and Dennis, two islands seventy miles to the north of Mahé, on the edge of the Seychelles Bank. He remained a fortnight on each, examining them in all their aspects. The former was barren, with a vast number of sea birds breeding upon it, while the latter was planted in coco nuts. Both proved to be formed entirely of coral material, rock and sand, and both were found to be gradually washing away into the sea. The surface reefs around them are insignificant, and they gave the impression of being the remains of reefs once widely extending along the north edge of the whole bank. On his return Mr. Fryer at once started down to visit the islands of Aldabra, Assumption, Cosmoledo, and Astove, among which he is to work for four months. These islands lie to the north-west of Madagascar, and due west of Farquhar Atoll, visited by the Sealark in 1905. Assumption and Aldabra form the most western group, the former being a crescent-shaped bank, $3^{\frac{1}{2}}$ miles long, and the latter a ring-shaped atoll, I9 miles long by 7 miles across, almost completely surrounded by land, with a shallow lagoon.

Astove and Cosmoledo form a second group, the former a ring-shaped atoll, 2 miles long, completely surrounded by land save for one passage to the south, and the latter an atoll, $9^{\frac{1}{2}}$ miles by 7 miles, lagoon 4 fathoms, ring much broken up, with eight main islands. Aldabra is well known as the home of gigantic land tortoises. Some rock from it in my possession contains abundant silica, a fact which makes the accompanying abstracts from Mr. Fryer's preliminary report on its adjacent islands of peculiar interest.

On July 24, accompanied by Mr. Scott, I went to Silhouette, the second highest island in the Seychelles, 2467 feet. We settled at 1600 feet, within the indigenous jungle, of which a square mile still exists. Here Mr. Scott remained until October $\mathrm{x}$, obtaining a rich collection of its insect fauna, which, allowing for the difference in the size and position of the islands, appeared to be to a large degree comparable in its nature to that of the Sandwich Islands. The island itself is about 12 square miles in extent, with rugged granite hills, and two bays with flats covered with coco nuts. These owe their existence to former fringing reefs, the level of the island having changed to the extent of at least 30 feet within comparatively recent times. The coco nut is grown up to 1200 feet, but the trees, as is also the case in Mahé, are infested with a fungoid disease, and do not bear well.

After a month in Silhouette I returned to Mahé, every part of which I visited in the ensuing seven weeks. For the most part I was occupied in examining its geographical teatures, rocks, reefs, and jungles, and in collecting its plants, of which I obtained upwards of 2000 sheets. I have little of general interest to add to my report in NaturE, January 25, 1906. Mahé showed the same change of level as Silhouette, and my former impression, that there might have been a more ancient elevation of about 200 feet, proved to be erroneous. Only about $2 \frac{1}{2}$ square miles of the indigenous iungle are now left, and that is being gradually affected by the reckless destruction of its larger trees. Mr. Scott is to collect its insects during the next four months, but it can scarcely be supposed that more than a small percentage of its indigenous fauna still manages to survive. This iungle area lies in the centre of the island, the north and south thirds of which,

1 For earlier reports see Nature, April 13, August 10, October 5, November 9 , December 21, 1905, and January 25, 1906. being almost completely deforested, have become physiologically dry, to the almost complete destruction of their indigenous flora and fauna. Much of the land, too has been destroved by cassava planting, which is followed on the steep hill-sides by the washing away of the soil, converting them into bare glacis.

\section{J. Stanley Groviner.}

Astove, where we arrived first, is an atoll about 2 miles long by $1 \frac{1}{2}$ miles broad; so far as I could tell it is entirely composed of elevatcd coral as a basis, with sand distributed in various places. The seaward beach in most parts is formed of sand, but in places coral rock forms small cliffs, showing very evident washing away. There is only one pass. This is narrow, and from the present rate of washing away must be of fairly recent date. On the westward side of the pass are "coral rock" cliffs, while on the east a good deal of piling up of big blocks has occurred. These blocks are all of coral rock, not dead corals. They appeared to have come partly from the present land (washed out) and partly from the reef, which, so far as I could see, was composed of coral rock only, and was not ordinary dead reef such as I saw at Bird Island, to the north of the Seychelles. The coral rock interested me very much. In places one could see regular fields of coral with all the corals in their natural positions, while here and there are small holes, 5 feet to 6 feet deep, with sides all encrusted with corals exactly as they grew. There was absolutely no question of piling up. The whole place is evidently exactly as it was underneath the sea. In parts of the island the corals have been more "metamorphosed" into rock (not retaining their original structure), but I could trace no correlation between the occurrence of this rock and its position on the island. In the north of the island there are some dunes about 50 feet high, purely of wind formation. I dug a hole on. the landward side of one, and found guano underneath with a sort of shingle one, and think the north-west monsoon must have been much stronger once, or cyclones more frequent, to have driven this shingle inland,

The lagoon is very shallow: bottom of fine coral (?) mud, which makes the whole lagoon white, and forms a froth all round the shore. There are one or two small islands near the pass. There will probably be two more "passes" formed soon, one to the N.N.E. and another to the S.E. The reef to the west is sandy, with little living coral. It falls directly to " no bottom" without any slope, so that a ship cannot anchor, but is moored by lines to the reef. I searched the reef opposite the pass, but found no living corals, only a piece or two of recently killed coral thrown up. As I have said before, it is rock, and not reef. In one place it drops to the sea in terraces, forming small waterfalls as the tide goes out.

The next island we went to, Cosmoledo, represents further stage in the Astove condition. There are only a few islands left. The settlement is on Menai, with a fishing station on Wizard. The rock is the same as at Astove, but naturally there is very much more sand. All round the reef the remains of islands stick up like rock mushrooms. On Menai Island there is a mangrove swamp on the lagoon side, trees mostly small, as the larger have been cut for their bark, used for tanning. There is a sand-dune, with some very old Casuarina. Everything was very dead and burnt up, and not nearly so attractive as at Astove. I went also to Wizard, Goëlette, and North East Islands. Wizard is very sandy, but has the distinction of having three good wells. I got a positive measure as to the rate of erosion, 15 yards having gone in the last fifteen years (measured by Spur's old house, which is now in the sea). Goëlette is of no interest except as containing some guano; North-East Island I only stayed on for a short time; all the guano has been dug, and is now being taken to the Cape. I caught a large lizard there, which occurs on none of the other islands, but it seems to me to be only a variety of the universal small one We had wretched weather, very squally, and I seem to have spent most of my time in a whale-boat trying to get to somewhere.

The next island, Assumption, is the most interesting of the three; it is not an atoll, and the settlement is a new one, so that everything is untouched. The rock is 